\title{
ROLE OF PSYCHIATRIST IN CONSULTATION-LIAISON PSYCHIATRY FOR BURN INJURY PATIENT
}

\author{
Nahdarina $\mathrm{R}^{*}$, Margono $\mathrm{H}^{* *}$ \\ * Dokter Umum, Peserta PPDS I Prodi Psikiatri Departemen/SMF Ilmu Kedokteran Jiwa FK UNAIR/RSUD dr. Soetomo Surabaya \\ **Guru Besar,Psikiater Konsultan, Staf Pengajar Departemen/SMF Ilmu Kedokteran Jiwa FK UNAIR/RSUD dr. Soetomo Surabaya
}

\begin{abstract}
Consultation-Liaison Psychiatry is sub specialistic in psychiatric as a connector in clinical service team, teaching and research in borderline between psychiatric and medical medicine/surgery science. Consultation-Liaison Psychiatry is the connector to all diagnoses, therapeutic, research and educational service which being done by psychiatrist in general hospital and as a bridge between psychiatrist and other specialists. Burn injury is one of the leading causes of death and disability in the world. Global Burden Disease's study reported approximately 265.000 deaths happened every year. According to WHO, 238.000 people died due to burn injury in 2000 and $95 \%$ of the death happened in developing and low income countries. Burn injury can be a remarkable traumatic, psychologic, social and economic experience. Physiologic changes can cause symptoms, both organic and psychiatric, starting from anxiety, delirium to psychosis. Psychiatric relation team can contribute substantially in order to manage this problem.
\end{abstract}

Keywords: Burn Injury Unit, Consultation-Liaison Psychiatry, Psychiatric

Corresponding author : Rini Nahdarina, dr.

Dep/SMF Kedokteran Jiwa FK UNAIR/RSUD Dr.Soetomo Surabaya HP: 081233938836 | email: cupo_riena@yahoo.com 


\section{PENDAHULUAN}

Pada luka bakar, kulit terpajan dengan energi panas dalam derajat tinggi sehingga terjadi kerusakan struktur kulit. Insiden luka bakar sangat bervariasi di berbagai wilayah dan negara di seluruh dunia [1-2]. Kulit merupakan organ tubuh yang paling besar memiliki berbagai berfungsi antara lain berperan sebagai pembatas antara lingkungan internal dan eksternal, meminimalisasi kehilangan cairan, menghalangi infeksi mikroba, termoregulasi, deteksi sensorik, dan surveilans imun. Oleh karena itu, hilangnya kulit, terutama dalam porsi besar, dapat menyebabkan risiko syok hipovolemik, dan sepsis serta berbagai akibat kesehatan lainnya [1-2].

Beberapa faktor yang memengaruhi kondisi psikologis pasien antara lain kondisi psikologis sebelumnya hingga berbagai masalah yang timbul selama perawatan luka bakar [3]. Masalah psikologis dilaporkan terjadi pada $28 \%$ hingga $75 \%$ pasien luka bakar [2]. Penelitian di salah satu burn center dengan pendekatan multidisiplin menunjukkan pentingnya peran psikiater sebagai bagian dari tim perawatan luka bakar, dimana sekitar $24,1 \%$ pasien membutuhkan konsultasi psikiatri [4].

Consultation-Liaison Psychiatry (CLP) merupakan suatu perkembangan lebih lanjut dari psikiatri klinik yang menjembatani psikiatri dengan dokter umum dan spesialis lainnya dalam pelayanan klinis, pengajaran, maupun penelitian [5]. Dalam CLP, psikiater berperan sebagai konsultan bagi sejawat kedokteran lain profesional kesehatan mental lainnya (psikolog, pekerja sosial, dan perawat psikiatri) [6]. Komunikasi yang baik dapat meningkatkan keefektifan proses konsultasi serta memastikan intervensi yang akurat, tepat waktu dan memberikan kemungkinan jenis penanganan lain yang lebih baik [7].

\section{PEMBAHASAN}

\section{Luka bakar}

Luka bakar merupakan kerusakan jaringan hidup yang disebabkan oleh panas, kimia, energi radiasi listrik atau kombinasi dari penyebab di atas. Cedera luka bakar yang parah menyebabkan kerusakan kulit yang luas dan dapat menyebabkan keadaan yang mengancam jiwa yang disebabkan ketidakseimbangan cairan dan elektrolit, gangguan metabolisme, kontaminasi bakteri dari jaringan, dan komplikasi di semua sistem organ utama [2]. Tingkat keparahan luka bakar berhubungan dengan luasnya kerusakan jaringan dan faktor individu terkait seperti proporsi permukaan tubuh, lokasi cedera, usia saat cedera, penyakit komorbid, dan masalah psikososial terkait seperti penyalahgunaan zat (alkoholisme) yang umum ditemukan [8].

Secara umum, luka bakar berdasarkan kedalamannya luka bakar dibagi menjadi luka bakar derajat 1 (superfisial), 2a (parsial superfisial), 2b (parsial dalam), dan 3 (full thickness). Proses penyembuhan dan tatalaksana dari luka bakar bergantung dari klasifikasi kedalaman tersebut. Luka bakar derajat pertama dapat sembuh secara spontan tanpa bekas dalam 1 minggu, sedangkan luka bakar derajat 3 membutuhkan 3 minggu untuk penyembuhan dan membutuhkan tatalaksana secara bedah seperti eksisi skin grafting [1].

Manajemen luka bakar mencakup pertolongan pertama, manajemen saluran napas, dan resusitasi cairan. Jika diperlukan, dilakukan eskarotomi dan perawatan luka. Perawatan dilakukan di unit khusus yang biasanya disebut burn unit atau burn center [1]. Burn center menyediakan pendekatan multidisiplin [4].

\section{Masalah pada pasien luka bakar yang memengaruhi kondisi psikiatri}

Gangguan psikiatri yang sudah ada sebelumnya relatif umum dalam riwayat pasien luka bakar dan sering berkontribusi secara signifikan terhadap etiologi cedera itu sendiri. Umumnya, 66,6\% pasien luka bakar memiliki riwayat setidaknya satu gangguan psikiatri selama hidupnya, $50 \%$ pasien memiliki gangguan psikiatri 1 tahun sebelum luka bakar, dan 33,3\% pasien memiliki gangguan psikiatri pada saat terjadinya luka bakar. Gangguan psikiatri yang paling sering ditemukan yaitu depresi (ditemukan pada $42 \%$ individu) dan penyalahgunaan zat. Gangguan kepribadian dan demensia merupakans salah satu faktor risiko terjadinya luka bakar [3]. Gangguan psikiatri yang sudah ada sebelumnya berhubungan dengan peningkatan waktu penyembuhan luka, angka operasi bedah, lama tinggal di rumah sakit, dan waktu rehabilitasi yang dibutuhkan [4]. Pasien dengan kondisi psikiatri premorbid memiliki risiko gangguan psikiatri setelah kejadian luka bakar yang lebih tinggi dibandingkan pasien tanpa kondisi premorbid [3]. Selain itu, gejala psikiatri dapat dipicu oleh gejala seperti nyeri, pruritus, dan stres yang terjadi selama perawatan dan dapat menyebabkan masalah seperti gangguan tidur dan depresi.

Nyeri

Nyeri yang terutama disebabkan oleh hiperalgesia mekanis primer merupakan salah satu keluhan yang paling sering ditemukan. Nyeri yang tidak ditangani dan 
berkepanjangan dapat berkontribusi terhadap masalah sensorik jangka panjang, termasuk nyeri kronis, parestesia, dan dyesthesias yang umum terjadi setelah luka bakar, serta memengaruhi kondisi psikologis pasien [9]. Peningkatan nyeri selama perawatan pada pasien luka bakar diasosiasikan dengan penyesuaian yang lebih buruk dan gangguan fungsi fisik hingga 2 tahun setelah perawatan. Selain itu, nyeri berhubungan dengan munculnya kecemasan yang dapat menjadi prediktor terjadinya gejala post traumatic stress disorder (PTSD) [10]. Lebih lanjut lagi, nyeri akut pada saat keluar dari rumah sakit diketahui menghasilkan ide bunuh diri pada pasien pasca luka bakar $[3,11]$.

\section{Pruritus}

Pruritus dilaporkan terjadi pada hingga $87 \%$ pasien luka bakar setelah keluar dari rumah sakit. Pruritus paling berat ditemui pada luka bakar derajat 3, memuncakpada satu sampai dua minggu, dan berkurang secara bertahap sesudahnya. Pruritus dikatakan bertahan hingga 18 bulan setelah luka bakar [2]. Pruritus yang terjadi dapat men- imbulkan kecemasan dan stres. Selain itu, pruritus juga dapat mengganggu tidur sehingga meningkatkan tingkat stres dan mengganggu fungsi dan partisipasi pasien dalam program rehabilitasi [3].

\section{Aspek psikiatri pasien luka bakar}

Eksplorasi berbagai reaksi psikologis pada pasien merupakan komponen penting dalam penanganan luka bakar. Gangguan mental dilaporkan terjadi pada $28 \%$ hingga $75 \%$ pasien luka bakar [2].

\section{Reaksi stress akut}

Reaksi stress akut adalah gangguan kejiwaan yang paling umum yang terlihat pada korban luka bakar dan memiliki prevalensi setinggi 19\% pasca luka bakar. Gejala reaksi stress akut muncul segera setelah trauma, berlangsung selama minimal 3 hari, dan biasanya sembuh dalam waktu satu bulan setelah trauma. Munculnya gejala penghindaran selama fase awal pemulihan diketahui dapat memprediksi gangguan kronis pasca-trauma pada pasien luka bakar. Reaksi stress akut dapat menjadi prediktor untuk terjadinya gangguan stress pasca trauma dan apabila gangguan stress pasca trauma terjadi, biasanya kondisi tersebut dapat berlangsung lama [3].

Gangguan stress pasca trauma (Post-Traumatic Stress Disorder/PTSD)

Gangguan stress pasca trauma (PTSD) adalah salah satu gangguan psikiatri yang paling sering ditemukan pada penyintas luka bakar mayor dengan prevalensi 7-45\%. Pasien PTSD mempunyai ketakutan terhadap kejadian yang telah terjadi yang dapat termanifestasi dalam mimpi buruk [3]. Gangguan stress pasca trauma diketahui berhubungan dengan luka bakar di daerah wajah, gangguan afektif pretrauma, gangguan kosmetik pada perempuan, serta pasien dengan ciri kepribadian neurotik [12]. Gejala klinis PTSD mencakup kesulitan tidur atau mudah terbangun, mudah marah, kurang perhatian, hypervigilance, dan reaksi terkejut yang berlebihan. Selain itu, emosi negatif meningkatkan ketidakberdayaan pasien dalam proses pemulihan mereka. Akibatnya, mereka memiliki coping berupa perilaku penarikan diri yang dapat memperparah gejala PTSD. Oleh karena itu pasien membutuhkan bimbingan dari para praktisi [13].

\section{Depresi}

Depresi pada pasien luka bakar berhubungan kuat dengan kondisi depresi pretrauma dan tingkat kesejahteraan yang rendah. Adanya gejala depresi selama perawatan juga merupakan prediktor depresi berkepanjangan setelah perawatan $[3,12]$. Selain itu, cacat pada tangan atau wajah yang terlihat juga secara signifikan dikaitkan dengan gejala depresi [14].

\section{Gangguan Cemas Menyeluruh}

Prevalensi gangguan cemas menyeluruh pada pasien luka bakar dewasa setahun setelah trauma yaitu $<20 \%$. Faktor yang dikaitkan dengan gangguan cemas menyeluruh yaitu mekanisme coping menghindar. Pada dewasa, kecemasan dapat diekspresikan melalui gejala panik seperti berkeringat, palpitasi, bergetar, atau mual, sedangkan pada anak, kecemasan dapat diekspresikan dengan menangis, merajuk, berdiam diri, atau menempel pada orang lain. Perlu dilakukan anamnesis yang teliti untuk membedakan gangguan cemas menyeluruh dari PTSD [3].

\section{Mekanisme koping pasien luka bakar}

Mekanisme koping merupakan usaha kognitif dan perilaku seseorang untuk menangani situasi stres serta emosi negatif yang menyertainya. Mekanisme koping dapat menjadi target rehabilitasi dan memiliki implikasi klinis dalam penanganan pasien luka bakar. Willebrand et al., menggunakan coping with burns questionnaire (CBQ) sebagai instrumen penilaian koping untuk pasien luka bakar. Penelitian ini juga melaporkan korelasi signifikan antara skor penghindaran pada CBQ dengan tingkat depresi [15].

Penelitian lain juga menunjukkan mekanisme koping aktif yang melibatkan pencarian dukungan sosial 
dikaitkan dengan luaran mental yang lebih baik sedangkan mekanisme penghindaran dikaitkan dengan luaran kesehatan mental yang lebih buruk. Menurut penyelitian oleh Bosmans, et al., 2015, mekanisme koping yang umum ditemukan adalah koping aktif, mencari dukungan sosial, menghindar, dan ekspresi emosional. Mekanisme koping dengan menghindar diasosiasikan dengan tingkat PTSD selama perawatan yang tinggi, sedangkan jenis koping ekspresi emosional dikaitkan dengan penyembuhan PTSD yang lebih baik [16].

\section{Psikiater sebagai bagian dalam tim CLP unit luka ba-}

kar

Berdasarkan studi yang dilakukan di sebuah burn center, konsultasi psikiatri dibutuhkan oleh $24,1 \%$ pasien dengan indikasi terbanyak yaitu kontrol nyeri dan kecanduan alkohol [4]. Ada empat elemen penting dalam perawatan paliatif bedah di ICU, yaitu komunikasi, tindakan dukungan hidup, manajemen gejala nyeri dan non - nyeri, dan dukungan duka cita. Empat elemen ini harus terintegrasi dalam praktek perawatan kritis dari tujuan pengobatan kuratif hingga paliatif [17].

Kualitas komunikasi tim dokter, perawat, pasien dan keluarga dianggap sebagai indeks kualitas keseluruhan perawatan pasien di ICU. Salah satu pendekatan klinis komunikasi adalah breaking bad news. Melakukan breaking bad news harus tepat waktu, tepat tempat, dengan bantuan dan back up yang sesuai, dengan izin pasien, setelah verifikasi fakta kritis, dan dilengkapi dengan penutupan dan rencana perawatan yang tepat setelah keluar dari rumah sakit. Semua ini harus dilakukan dengan lembut, efisien, dan pendekatan positif. Terdapat hubungan yang kuat antara persepsi pasien yang menerima informasi adekuat tentang penyakit dan pengobatannya dengan penyesuaian psikologis pasien dalam jangka waktu yang lebih lama.

\section{Tahap pemulihan pasien gangguan psikiatri pada pasien luka bakar}

Pemulihan luka bakar dapat dibagi menjadi empat fase yaitu fase awal masuk rumah sakit, perawatan kritis, pemulihan di rumah sakit, serta rehabilitasi dan reintegrasi (tabel 1)
Tabel 1. Tahap Pemulihan dengan gejala psikososial yang diharapkan dan perawatan yang disarankan $[10,18$ 19]

\begin{tabular}{lll}
\hline Fase & Gejala yang mungkin ditemukan & Terapi yang direkomendasikan \\
\hline Awal masuk & Kecemasan, teror & Obat anticemas \\
rumah sakit & Nyeri & Obat antinyeri \\
& Sedih, berduka & Dukungan psikologis berupa \\
& Represi dan denial & reassurance, normalisasi, teknik \\
& & relaksasi \\
Perawatan & Seperti gejala di atas & Obat Anticemas \\
masa kritis & Gangguan stres akut & Obat Antinyeri \\
& Sindrom depresi, regresi, atau & Obat dengan target gejala \\
& atau psikosis & gangguan stres akut \\
& Perubahan kognitif & Melanjutkan dukungan \\
& & psikologis \\
& & Mengembangkan mekanisme \\
& & koping pasien \\
Masa & Peningkatan nyeri dengan latihan & Mengatasi nyeri \\
penyembuha & Marah, mengamuk & Psikoterapi (CBT dan terapi \\
& Berduka & keluarga) \\
& Episode depresi, perubahan & Terapi farmakologi untuk cemas \\
& emosional yang cepat & dan depresi \\
& & \\
Rehabilitasi & Kesulitan dalam menyesuaikan & Memulai program di atas \\
dan & diri & kembali \\
reintegrasi & PTSD & Pengobatan PTSD \\
& Kecemasan dan fobia & Psikoterapi (CBT, terapi \\
& Depresi & keluarga, social skill) \\
& & Tappering offobat anticemas \\
& & Obat antidepresan \\
\hline & & \\
& & \\
& & \\
& & \\
& & \\
& &
\end{tabular}

\section{Kualitas hidup pasien luka bakar}

Jaringan parut atau bekas luka yang timbul pasca trauma luka bakar dapat menyebabkan perubahan pada citra atau penampilan tubuh, juga bersifat traumatis dan menimbulkan respons psikopatologis. Masalah di bidang psikis dan mental seringkali lebih merugikan penderita daripada masalah fisik, contohnya adalah masalah sosial yang timbul seperti kesulitan dalam kehidupan seksual dan interaksi sosial. Namun, kualitas hidup pasien luka bakar dapat kembali dalam rata-rata 6 bulan. Sekitar 79\% pasien dapat kembali bekerja atau sekolah dan hanya $45 \%$ yang membutuhkan penyesuaian dalam pekerjaan. Faktor penting yang berperan dalam keberhasilan tersebut adalah kemampuan keluarga untuk mendukung dan membantu dalam pengobatan jangka panjang dan penyesuaian diri pasien. Selain itu, penting dilakukan skrining rutin gejala psikologis sebagai identifikasi awal pasien yang berisiko, sehingga memungkinkan intervensi psikoterapi yang tepat dan dengan demikian dapat membantu meningkatkan kualitas hidup dan kesejahteraan umum pasien luka bakar dalam jangka panjang. Pasien luka bakar seringkali memerlukan rehabilitasi, rekonstruksi, dan dukungan psikososial selama bertahun-tahun. Oleh karena itu, terapi psikiatri harus dimasukkan pada setiap tahap perawatan untuk penyesuaian dan kualitas hidup yang lebih baik pada pasien luka bakar [20]. 


\section{RINGKASAN}

Consultation-Liaison Psychiatry (CLP) merupakan suatu perkembangan lebih lanjut dari psikiatri klinik yang menjembatani psikiatri dengan dokter umum dan spesialis lainnya dalam pelayanan klinis, pengajaran, maupun penelitian. Dalam CLP, psikiater berperan sebagai konsultan bagi sejawat kedokteran atau profesional kesehatan mental lainnya. Burn center sebagai tempat unit khusus perawatan luka bakar menyediakan pendekatan multidisiplin dan menempatkan psikiatri sebagai komponen yang penting.

Pasien luka bakar seringkali mempunyai gangguan psikiatri yang sudah ada sebelumnya dan sering berkontribusi secara signifikan terhadap kejadian cedera itu sendiri. Selain itu, pasien akan mempunyai gejala psikiatri selama proses pengobatan luka bakar yang dikarenakan gejala seperti nyeri, pruritus, dan stress. Gangguan kejiwaan yang sering ditemukan antara lain Acute Stress Disorder, PostTraumatic Stress Disorder, depresi, dan gangguan cemas menyeluruh. Psikiater memiliki empat peran utama di ICU yang mencakup komunikasi, tindakan dukungan hidup, manajemen gejala nyeri dan non- nyeri, dan dukungan duka cita. Pemulihan luka bakar dibagi menjadi fase awal masuk rumah sakit, perawatan kritis, pemulihan di rumah sakit, serta rehabilitasi dan reintegrasi. Pada setiap fase, terdapat gejala psikososial yang umum ditemukan sehingga dengan memahami hal tersebut maka psikiater dapat memberikan terapi yang tepat sesuai dengan apa yang dibutuhkan pasien. Tatalaksana psikososial yang tepat dan dukungan keluarga akan membantu pasien dalam mendapatkan kualitas hidup yang lebih baik.

\section{DAFTAR PUSTAKA}

[1] Walls R, Hockberger R, Gausche-Hill, M. Rosen's Emergency Medicine. Edisi 9USA: Elsevier Inc; 2018.

[2] Ramachandran M, Durairaj AR, Mahipathy SRRV, Sundaramurthy N. Analysis of psychiatric problems in burn patients in a tertiary burn unit: a prospective study. Int J Surg. 2017;4(12).

[3] Herndon D. Total Burn Care. 5th ed. USA: Elsevier Inc; 2017.

[4] Moore M, Fagan S, Nejad S, Bilodeau M, Goverman $\mathrm{L}$, Ibrahim AE, et al. The role of a dedicated staff psychiatrist in modern burn centers. Ann Burns Fire Disasters. 2013; 26(4): 213-6.

[5] Wardani IAK. Makalah penelitian tentang pengenalan consultation liasion psychiatry pada bidang medis lain. Indonesia: Fakultas Kedokteran Udayana; 2017.

[6] Sadock BJ, Sadock VA, Ruiz P. Kaplan and Sadock's Synopsis of Psychiatry: Behavioral Science/Clinical Psychiatry. 11th ed. USA: Wolters Kluwer; 2014.

[7] Syamsulhadi M, Septiawan D. Implementasi consultation liaison psychiatry di beberapa bidang medis. Indonesia: Muhammadiyah University Press; 2016.

[8] Shanmugakrishnan RR, Narayanan V, Thirumalaikolundusubramanian P. Epidemiology of burns in a teaching hospital in south India. Indian $\mathbf{J}$ of Plast Surg. 2008;41(1):37-7.

[9] Summer GJ, Puntillo KA, MIaskwoski C, Green PG, Levine JD. Burn injury pain: the continuing challenge. J Pain. 2007;8(7):533-48.

[10] Dalal PK, Saha R, Agarwal M. Psychiatric aspects of burn. Indian J Plast Surg. 2010;43:136-42.

[11] Jain M, Khadilkar N, Sousa AD. Burn-related factors affecting anxiety, depression and self-esteem in burn patients: an exploratory study. Ann Burns Fire Disasters. 2017;30(1):30-4.

[12] Fauerbach JA, McKibben J, Bienvenu OJ, MagyarRussell G, Smith MT, Holavanahalli R. Psychological distress after major burn injury. Psychosom Med. 2007;69(5):473-82.

[13] Cheng H, Li X, Xiao H, Li R. The role of coping behavior in severely burned patients with posttraumatic stress disorder. J Neuropsychiatry Clin Neurosci. 2015;27(3):188-92.

[14] Madianos MG, Papaghelis M, Ioannovich J, Dafni R. Psychiatric disorders in burn patients: A follow-up study. Psychother Psychosom. 2001;70(1):30-7.

[15] Bras M, Loncar Z, Brajkovic L, Gregurek R, Mickovic V. Coping with severe burns in the early stage after burn injury. Coll Antropol. 2007;31(1):159-63.

[16] Bosmans MWG, Hofland HW, Jong AED, Loey NEV. Coping with burns: the role of coping self-efficacy in the recovery from traumatic stress following burn injuries. J Behav Med. 2015;38(4): 642-51.

[17] Dunn GP, Mosenthal AC. Palliative care in the surgical intensive care unit: where least expected, where most needed. Asian J Surg. 2007;30(1):1-5.

[18] Blakeney PE, Rosenberg L, Rosenberg M, Faber AW. Psychosocial care of persons with severe burns. Burns. 2008;34(4):433-40.

[19] Mandelsohn IE. Liaison psychiatry and the burn center. Psychosomatics. 1983;24(3):235-4

[20] Malik P, Garg R, Sharma KC, Jangid P, Gulia A. Quality of life in burn injury patients. Delhi Psychiatry Journal. 2012;15(2):308-15. 